\title{
NORMAL VARIATION IN THE DENSITY OF SELECTED HUMAN BONES IN NORTH INDIA
}

\author{
A Necropsy Study \\ M. Ahuja, Delhi, India \\ From the Department of Pathology, All-India Institute of Medical Sciences, New Delhi
}

In the past decade several attempts have been made to develop precise methods of measuring bone mass and the loss of bone mass that occurs with ageing. Yet our knowledge of the normal variations in bone mass that take place in males and females with age, and in different parts of the body, is still inadequate. Comparison of the findings in different reports is difficult due to differences in methods of evaluation or in bone sites studied. Radiological assessment of mineralisation of bone can be misleading. It is recognised that calcium loss may be in the vicinity of 30 per cent to 50 per cent before it can be detected radiologically. A number of densitometric techniques have been introduced to enable a semi-quantitative assessment of bone density. Because of the many problems involved in measuring the density of the vertebrae, measurement of the cortical thickness of peripheral bone in radiographs has become a more commonly used index of skeletal mass (Barnett and Nordin 1960; Meema and Meema 1963; Smith and Frame 1965; Morgan, Spiers, Pulvertaft and Fourman 1967). It is, however, still uncertain whether changes in bone density affect all parts of the skeleton equally and simultaneously. To what extent the changes in the peripheral bones represent the state of axial skeleton is not fully known.

Measurement of bone density as coefficient of bone weight by volume is an objective index of bone mass (Robinson and Elliott 1957; Trotter, Broman and Peterson 1960; Baker and Angel 1965; Mueller, Trias and Ray 1966), and apparent density of spongy bone seems to be a sensitive method for assessment of its porosity (Lindahl and Lindgren 1962). Estimation of bone ash per unit volume of bone is also a valuable method for the study of bone composition and mass (Trotter and Peterson 1955; Wray, Sugarman and Schneider 1963; Arnold 1964).

Bone weights, bone densities, mineral content of bone and compact bone thickness may vary according to age, sex, race and nutrition. The skeletal weight of the American Negro is reported to be higher than that of the American white (Seale 1959), and the bones of the negro skeleton are denser than those of the white skeleton of comparable age and sex (Trotter et al. 1960, Baker and Angel 1965). In South Africa, vertebrae of the Bantu subjects are reported to have higher density than those of the whites (Walker, Strydom, Reynolds and Grobbelaar 1955). In epidemiological studies Smith and Rizek (1966) found a higher proportion of native Puerto Rican women with lower density of vertebral bodies assessed radiologically when compared with Michigan women. In the same study it was also evident that amongst the Caucasian women of Michigan those of British ancestry had a significantly higher incidence of vertebral atrophy than the rest. Garn, Pao and Rihl (1964) in a study of American subjects of Chinese and Japanese ancestry, which included American-born as well as those born elsewhere, found that the compact bone thickness in these subjects was significantly less than the age and sex specific standards for Americans of European ancestry. Nordin (1966) reported that radiological measurement of the metacarpal bone in Japanese and Indian women was distinctly lower than that of British and American women.

Adequate knowledge about the bone mass in various population groups with different racial, genetic, climatic and nutritional backgrounds, and about the manner in which bone 
mass is influenced by age and sex, is essential before the extent of bone loss can be assessed for any given population group. The establishment of normals in this respect is necessary, irrespective of whether age-related bone loss is considered a normal consequence of senescence or of disease.

This paper reports a study made to find out the variations in skeletal mass that occur with age and sex in the normal Indian population in the Delhi area. The skeletal material was obtained from necropsy subjects who had died suddenly: it included samples from the axial as well as appendicular skeleton. The parameters for the study of bone mass included apparent bone density, bone ash per millilitre of bone and cortical bone thickness.

\section{MATERIAL}

The bones were collected from persons dying suddenly whose remains were examined for medico-legal purposes at the Forensic Medicine Unit of this Institute in two and a half

TABLE I

Distribution of Cases with Respect to Age and Sex (200 cases)

\begin{tabular}{|l|c|cc|c|c|c|c|c|c|}
\hline $\begin{array}{l}\text { Age group } \\
\text { (years) }\end{array}$ & $0-9$ & $10-19$ & $20-29$ & $30-39$ & $40-49$ & $50-59$ & $60-69$ & $70-79$ & Total \\
\hline Male & 2 & 11 & 39 & 21 & 24 & 26 & 16 & 10 & 149 \\
Female & 3 & 8 & 15 & 9 & 6 & 5 & 3 & 2 & 51 \\
\hline Total & 5 & 19 & 54 & 30 & 30 & 31 & 19 & 12 & 200 \\
\hline
\end{tabular}

TABLE II

Distribution of Cases With Respect to the Broca IndeX

\begin{tabular}{|ccccc|}
\hline \multicolumn{3}{c}{ Broca index } & \multicolumn{2}{c|}{ Cases } \\
& & Number & Per cent \\
\hline-6 and more & (underweight) &. & 100 & $55 \cdot 5$ \\
-5 to +5 & (normal weight) &. & 58 & $32 \cdot 3$ \\
+6 to +15 & (overweight) &. & 21 & $11 \cdot 6$ \\
+16 and more (marked overweight) & 1 & $0 \cdot 6$ \\
\hline \multicolumn{2}{c}{ Total } &. & 180 & 100 \\
\hline
\end{tabular}

years. Most of the deaths were from road accidents; other causes included drowning, poisoning, burns, hanging and shooting. Persons treated in bed in the hospital for more than four days and those found at the time of necropsy to have any chronic disease were excluded.

A total of 200 cases was collected. The age and sex distribution is shown in Table I. There were 149 men and fifty-one women, varying in age from nine months to seventy-six years. Sixty-two subjects were over fifty years of age and another thirty were between forty and forty-nine years of age. The height, weight and nutritional state as assessed from depot fat and external appearance were recorded in most instances. The normal weight for the subjects was calculated from Broca's formula and results were expressed as below and above the "ideal" weight (Table II). 

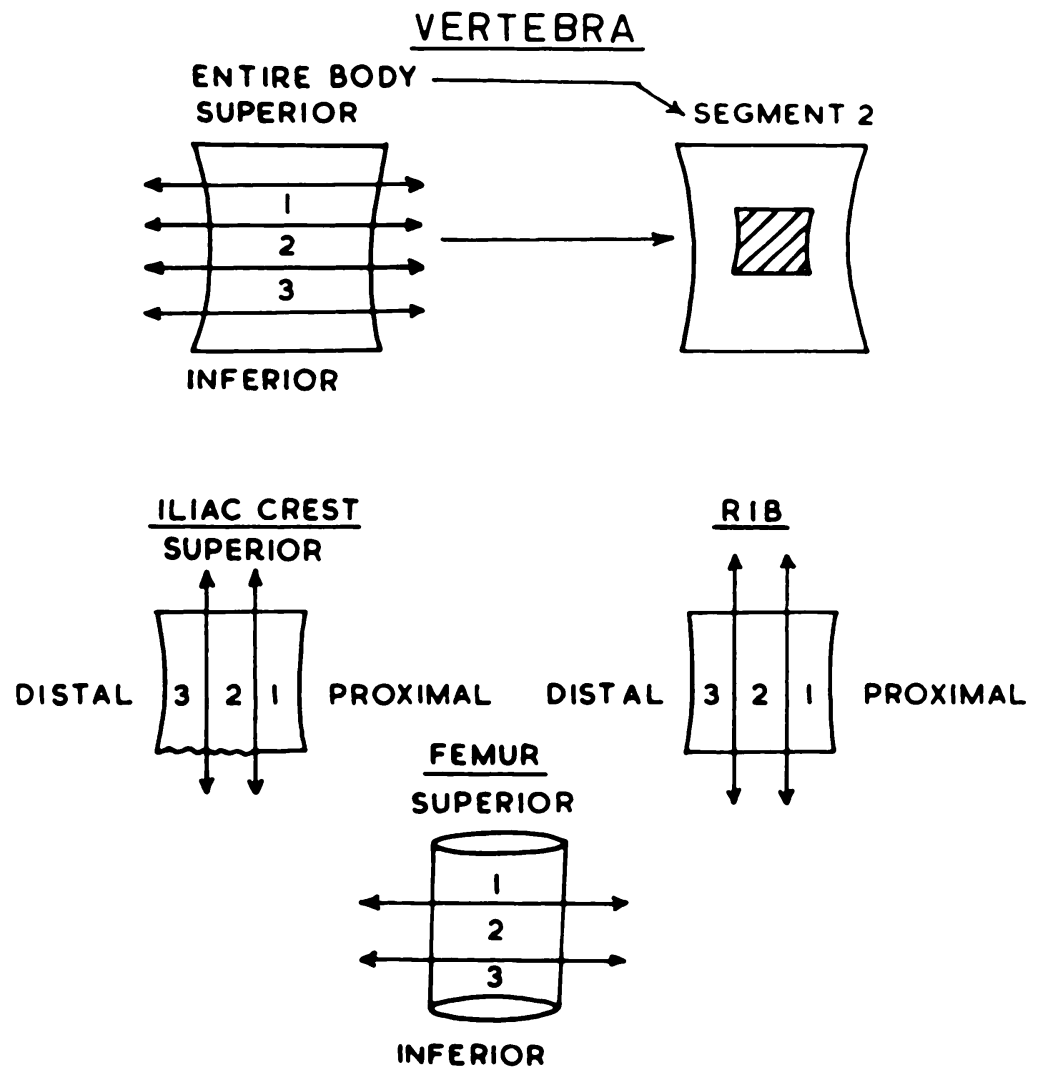

Fig. 1

Diagram showing the slicing and labelling of the various bone segments taken for examination.

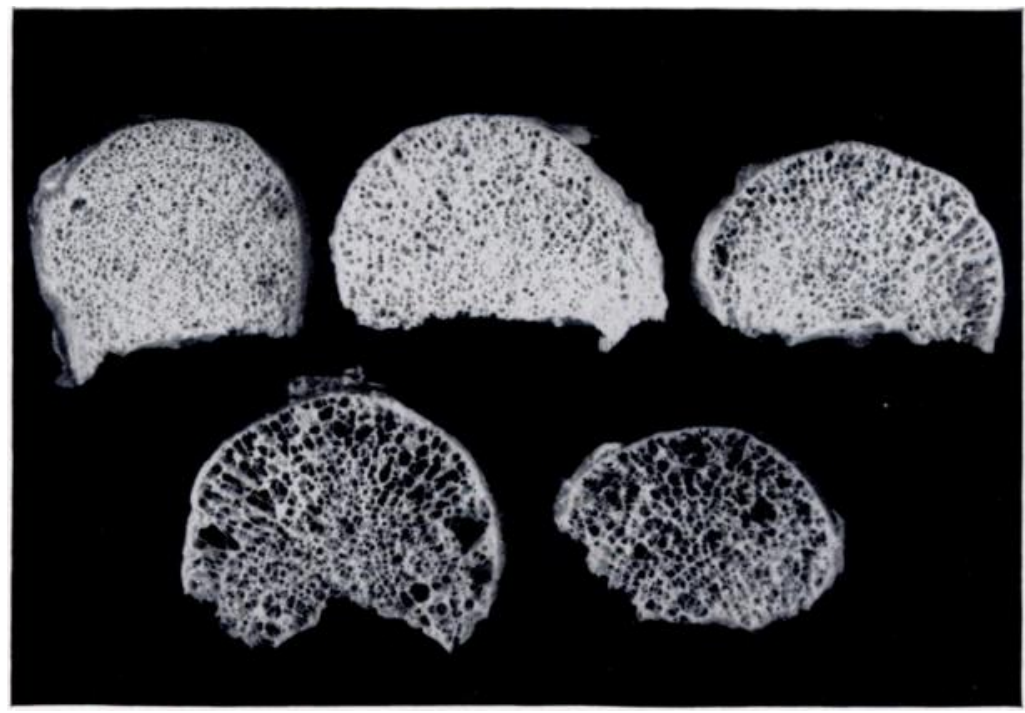

Fig. 2

Photograph of the macerated bone segments of vertebra showing different grades of porosity. Top line (left to right): Grades 0 , I and II. Bottom line (left to right): Grades III and IV. 


\section{METHODS}

The bones were stored frozen until processed. Each bone was sliced with an electric saw into three segments which were labelled as segments 1, 2 and 3. To avoid sampling error, slicing was done at standard sites as shown in Figure 1. Segment 1 in all bones was used for maceration; segment 2 was used for density determination; and segment 3 for light microscopic study of decalcified sections. Segment 2 of vertebra was further trimmed so as to take only the central medullary

TABLE III

Apparent Bone Density of Vertebral Medullary Tissue in Relation to Age and Sex (200 cases)

\begin{tabular}{|c|c|c|c|c|c|c|c|c|c|}
\hline \multirow{2}{*}{$\begin{array}{c}\text { Age } \\
\text { (years) }\end{array}$} & & \multicolumn{3}{|c|}{ Female } & \multicolumn{3}{|c|}{ Combined (male and female) } \\
\hline & $\begin{array}{l}\text { Number of } \\
\text { cases }\end{array}$ & Mean & S.D. & $\begin{array}{l}\text { Number of } \\
\text { cases }\end{array}$ & Mean & S.D. & $\begin{array}{l}\text { Number of } \\
\text { cases }\end{array}$ & Mean & S.D. \\
\hline $0-9$ & 2 & $0 \cdot 2229$ & \pm 0.0236 & 3 & $0 \cdot 2267$ & $\therefore 0.0492$ & 5 & 0.2252 & $\therefore 0.0423$ \\
\hline $10-19$ & 11 & $0 \cdot 2228$ & $=0.0443$ & 8 & $0 \cdot 2814$ & $\therefore 0.0793$ & 19 & $0 \cdot 2476$ & $\therefore 0.0612$ \\
\hline $20-29$ & 39 & $0 \cdot 2886$ & $=0.0734$ & 15 & 0.2793 & $=0.0553$ & 54 & $0 \cdot 2860$ & $=0.0690$ \\
\hline $30-39$ & 21 & $0 \cdot 2571$ & \pm 0.0574 & 9 & $0 \cdot 2647$ & $=0.0401$ & 30 & 0.2594 & 0.0531 \\
\hline $40-49$ & 24 & $0 \cdot 2546$ & $=0.0634$ & 6 & $0 \cdot 2449$ & $=0.0686$ & 30 & 0.2527 & 0.0644 \\
\hline $50-59$ & 26 & $0 \cdot 2390$ & \pm 0.0664 & 5 & 0.2256 & 0.0414 & 31 & 0.2392 & $\therefore 0.0636$ \\
\hline $60-69$ & 16 & $0 \cdot 2124$ & 0.0597 & 3 & $0 \cdot 1684$ & $=0.0714$ & 19 & 0.2055 & $\div 0.0612$ \\
\hline $70-79$ & 10 & $0 \cdot 2023$ & 0.0519 & 2 & 0.1339 & $=0.0067$ & 12 & $0 \cdot 1909$ & $\div 0.0492$ \\
\hline
\end{tabular}

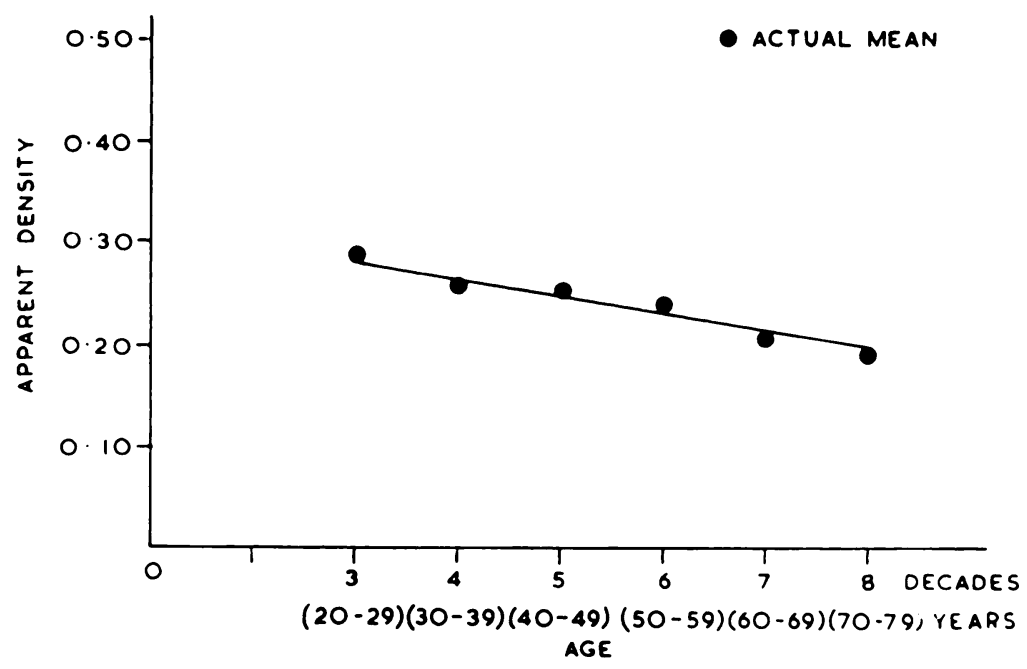

FIG. 3

Regression line of apparent density of vertebral medullary tissue on age in decades (males and females combined).

portion for study. The iliac crest and rib segments included both the cortical and trabecular parts. The piece of vertebra was also used for determination of bone ash content.

Maceration-The bone piece was first put in water for twenty-four hours and then in a 3 per cent solution of sodium hydroxide for two to three hours. The marrow was then completely washed out with a jet of water and all extra soft tissue removed. The bone was put in 3 per cent hydrogen peroxide for twelve hours and later dried and kept for grading. 
Apparent bone density-The piece of bone was freed from all soft tissue and marrow elements by washing with a jet of water and dried in an oven at 100 degrees Centigrade and weighed after forty-eight hours. This was taken as the dry weight of the bone. In the beginning, weights were checked after every twenty-four hours of drying up to a period of ten days. A constant weight was attained after forty-eight hours. Drying for forty-eight hours at 100 degrees Centigrade was, therefore, adopted as the standard procedure for all cases.

TABLE IV

Mean Ash Content (Grammes/Millilitre) of Vertebral Medullary Tissue in Relation to Age and Sex (200 cases)

\begin{tabular}{|c|c|c|c|c|c|c|c|c|c|}
\hline \multirow{2}{*}{$\begin{array}{c}\text { Age } \\
\text { (years) }\end{array}$} & \multirow[b]{2}{*}{$\begin{array}{l}\text { Number of } \\
\text { cases }\end{array}$} & \multirow{2}{*}{$\begin{array}{l}\text { Male } \\
\text { Mean }\end{array}$} & \multirow[b]{2}{*}{ \pm S.D. } & \multirow[b]{2}{*}{$\begin{array}{l}\text { Number of } \\
\text { cases }\end{array}$} & \multirow{2}{*}{$\begin{array}{c}\text { Female } \\
\text { Mean }\end{array}$} & \multirow[b]{2}{*}{ :S.D. } & \multicolumn{3}{|c|}{ Combined (males and females) } \\
\hline & & & & & & & $\begin{array}{c}\text { Number of } \\
\text { cases }\end{array}$ & Mean & \pm S.D. \\
\hline $0-9$ & 2 & $0 \cdot 1236$ & \pm 0.0305 & 3 & $0 \cdot 1284$ & $\therefore 0.0362$ & 5 & $0 \cdot 1265$ & $\therefore 0.0344$ \\
\hline $10-19$ & 11 & $0 \cdot 1326$ & \pm 0.0270 & 8 & $0 \cdot 1748$ & \pm 0.0468 & 19 & $0 \cdot 1502$ & 0.0365 \\
\hline $20-29$ & 39 & $0 \cdot 1769$ & \pm 0.0499 & 15 & $0 \cdot 1717$ & $\div 0.0424$ & 54 & $0 \cdot 1755$ & $\therefore 0.0443$ \\
\hline $30-39$ & 21 & $0 \cdot 1558$ & \pm 0.0346 & 9 & $0 \cdot 1607$ & $\therefore 0.0255$ & 30 & $0 \cdot 1573$ & \pm 0.0322 \\
\hline $40-49$ & 24 & $0 \cdot 1550$ & \pm 0.0384 & 6 & $0 \cdot 1488$ & $\doteq 0.0419$ & 30 & $0 \cdot 1538$ & $\therefore 0.0387$ \\
\hline $50-59$ & 26 & $0 \cdot 1457$ & \pm 0.0435 & 5 & $0 \cdot 1420$ & 0.0356 & 31 & $0 \cdot 1436$ & $=0.0425$ \\
\hline $60-69$ & 16 & $0 \cdot 1287$ & $\leftarrow 0.0579$ & 3 & $0 \cdot 1057$ & $=0.0415$ & 19 & $0 \cdot 1251$ & $=0.0404$ \\
\hline $70-79$ & 10 & $0 \cdot 1242$ & -0.0323 & 2 & 0.0850 & $\therefore 0.0000$ & 12 & $0 \cdot 1177$ & $\div 0.0323$ \\
\hline
\end{tabular}

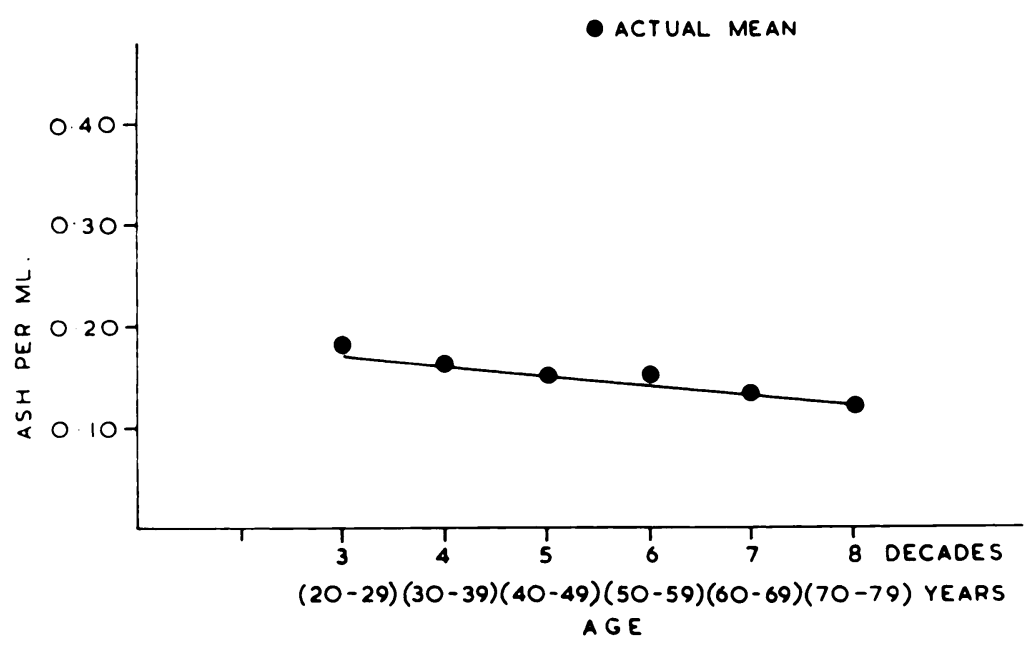

Fig. 4

Regression line of ash content per millilitre of vertebral medullary tissue on age in decades (males and females combined).

After determination of the dry weight, the same bone piece was coated with paraffin and the excess wax was removed with a scalpel. The amount of water displaced by it in a locally designed pykometer was measured. The apparent density was determined by dividing the dry weight of the bone by its surface volume-thus

$$
\text { Apparent density }=\frac{\text { Dry weight in grammes }}{\text { Surface volume in millilitres }} .
$$

VOL. 51 B, NO. 4, NOVEMBER 1969 
TABLE V

Distribution of the Visual Grades of Porosity with Respect to Age

(200 cases)

\begin{tabular}{|c|c|c|c|c|c|c|c|c|c|}
\hline \multirow{3}{*}{$\begin{array}{c}\text { Age } \\
\text { (years) }\end{array}$} & \multirow{3}{*}{$\begin{array}{l}\text { Total number } \\
\text { in each } \\
\text { decade }\end{array}$} & \multicolumn{7}{|c|}{ Grade of porosity } & \multirow[b]{3}{*}{ Per cent } \\
\hline & & \multicolumn{4}{|c|}{$\mathbf{0}$} & \multicolumn{3}{|c|}{ I } & \\
\hline & & Male & Female & Total & Per cent & Male & Female & Total & \\
\hline $0-9$ & 5 & 2 & 2 & 4 & $80 \cdot 0$ & - & 1 & 1 & $20 \cdot 0$ \\
\hline $10-19$ & 19 & 3 & 1 & 4 & $21 \cdot 0$ & 4 & 4 & 8 & $42 \cdot 0$ \\
\hline $20-29$ & 54 & 10 & 3 & 13 & $24 \cdot 0$ & 18 & 7 & 25 & $46 \cdot 5$ \\
\hline $30-39$ & 30 & 4 & 1 & 5 & $16 \cdot 6$ & 10 & 6 & 16 & $53 \cdot 3$ \\
\hline $40-49$ & 30 & 4 & - & 4 & $13 \cdot 3$ & 6 & 3 & 9 & $30 \cdot 0$ \\
\hline $50-59$ & 31 & 3 & 1 & 4 & $13 \cdot 0$ & 10 & - & 10 & $32 \cdot 2$ \\
\hline $60-69$ & 19 & 3 & - & 3 & $15 \cdot 8$ & 2 & - & 2 & $10 \cdot 5$ \\
\hline $70-79$ & 12 & 1 & - & 1 & $8 \cdot 3$ & 1 & - & 1 & $8 \cdot 3$ \\
\hline $\begin{array}{l}\text { Total n } \\
\text { Percent } \\
\text { Mean a } \\
\pm \text { S.D. }\end{array}$ & $\begin{array}{l}\text { mber in each g } \\
\text { ge distribution }\end{array}$ & \multicolumn{3}{|c|}{$\begin{array}{r}\text { f cases grade vise } \\
\qquad \begin{array}{r}30 \cdot 51 \\
\pm 18.0\end{array}\end{array}$} & $19 \cdot 0$ & & \multicolumn{2}{|c|}{$\begin{array}{r}72 \\
32.90 \\
\pm 13.9\end{array}$} & $36 \cdot 0$ \\
\hline
\end{tabular}

Bone ash-The piece of vertebra used for apparent density study was deparaffinised and ashed in a Muffle furnace at 560 degrees Centigrade for forty-eight hours. The ash was weighed and the results expressed as grammes of ash per millilitre of bone.

Histological study-Bone pieces were decalcified in 5 per cent nitric acid. The decalcified pieces were embedded in paraffin, cut at $5 \mu$ thickness and stained with haematoxylin and eosin.

Gross visual grading-The macerated segments of vertebrae were graded visually in five grades of porosity from 0 to 4 as shown in Figure 2. The validity of visual grading was tested in the following manner. Five randomly selected specimens from each grade were calibrated by counting the number of spaces within a given constant area when the specimen was photographed at a fixed distance and magnified fifteen times. The average number of spaces counted in three areas photographed in each specimen was taken and the overall mean for each grade calculated. A significant separation of the different visual grades was confirmed on the basis of a statistically significant difference between the mean number of holes in the various grades. The same randomly selected specimens were radiographed and placed in five grades by a radiologist without knowledge of the visual grades. A good correlation was observed between the visual and radiological grading.

Femur score-The thickness of femoral cortex and the diameter of shaft were measured by calipers in two diagonally opposite directions and the mean thickness and diameter determined. The "score" was calculated by the following formula (Barnett and Nordin 1960):

$$
\text { Femur score }=\frac{\text { Medial cortical thickness }+ \text { lateral cortical thickness }}{\text { Diameter of shaft }} \text {. }
$$

\section{RESULTS}

VERTEBRA

Apparent density-The mean apparent density of the vertebral medullary tissue for males and females for each decade is shown in Table III. There is a rise in the apparent density up to the third decade and a decline thereafter. Regression analysis done from the third decade onwards-that is, after the age of twenty-for each sex revealed a highly significant linear regression of apparent density with age in both males and females ( $\mathrm{P}$ value $<\cdot 001)$. Although the decline seems to be more marked in females than in males, the differences between these 
TABLE V-continued

Distribution of the Visual Grades of Porosity with Respect to Age

(200 cases)

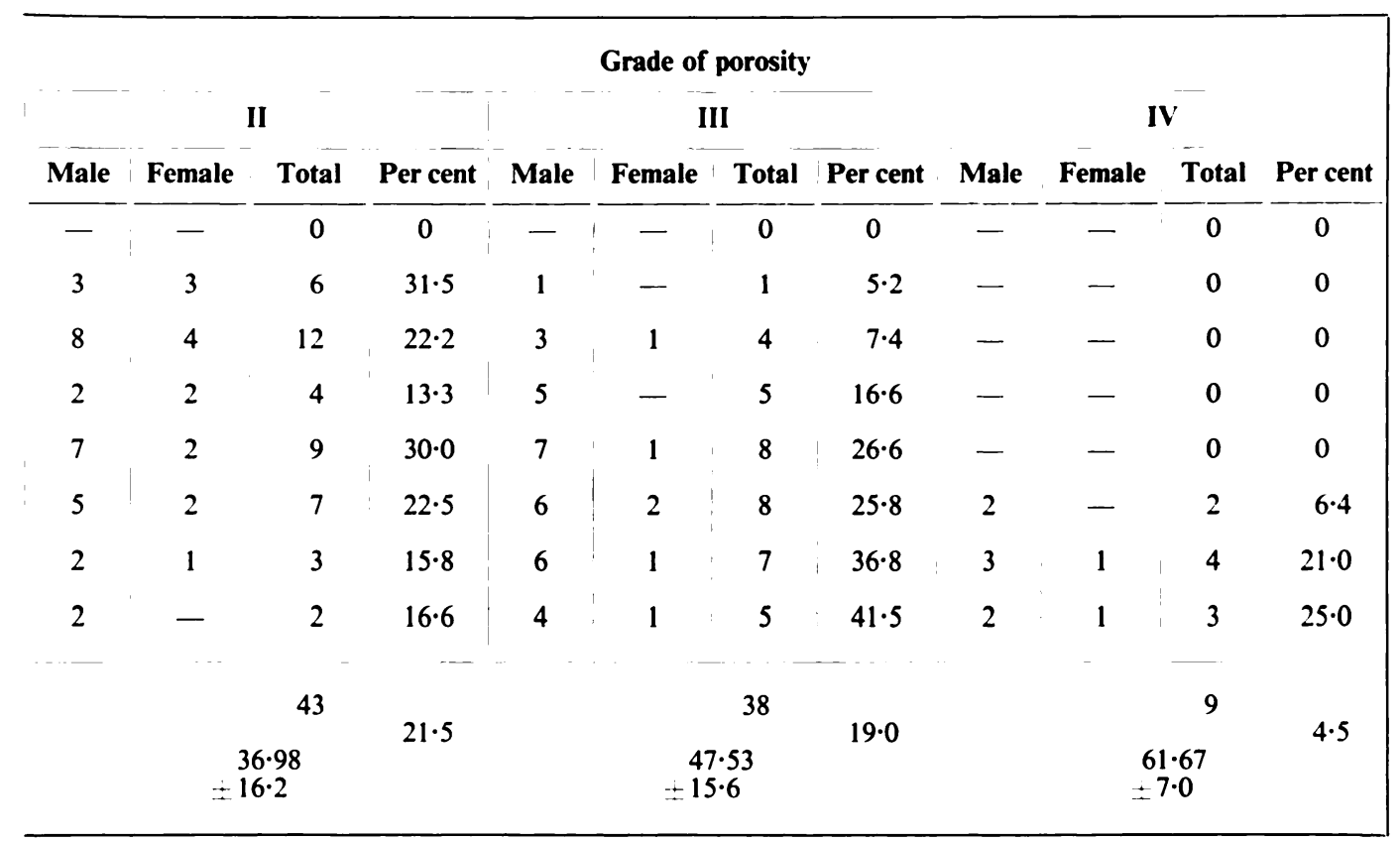

lines are not statistically significant $(P>0 \cdot 2)$. Therefore, a common regression line for males and females together was constructed. The slope of the linear regression line for the combined data is also highly significant $(\mathrm{P}<\cdot 001)$ (Fig. 3).

For the combined regression there is a decrease of 0.0172 in apparent density per decade, giving an average decrease of 6.1 per cent of the expected value at the third decade. When the observed mean apparent density in the third and eighth decades is taken into consideration, the rate of decrease per decade is found to be 6.6 per cent of the observed mean at the third decade.

Ash content-Ash content per millilitre of vertebral medullary tissue in males and females in relation to age in decades is shown in Table IV. There is a rise up to the third decade and then a decline. Regression analysis done as in the case of apparent density reveals highly significant linear regression of ash per millilitre on the age in decades from the third decade onwards both in males and females $(\mathrm{P}<\cdot 001)$. Although the females show a more marked decrease than males, the difference between these lines is not statistically significant $(P>0 \cdot 2)$. The combined line for both sexes shows a highly significant regression slope with a $\mathbf{P}$ value $<\cdot 001$ (Fig. 4). The decrease in ash per millilitre per decade is 0.0107 , at a rate of 6.2 per cent of expected value at the third decade. A highly significant positive correlation was found between the apparent bone density and ash per millilitre of vertebra in the individual cases $(r=+\cdot 96$, $\mathrm{P}<\cdot 001$ (Fig. 5)).

Visual grading-Table $\mathrm{V}$ shows the distribution of cases according to the grade of porosity visible to the naked eye on macerated vertebral bone segments. An association between age and grade of porosity is seen (Chi. $\frac{2}{12}=46 \cdot 84, \mathrm{P}<\cdot 001$ ). The per cent of cases in Grades III and IV increases successively from one age group to the other. Grade IV porosity did not appear before fifty years of age, but between seventy and seventy-nine years of age 25 per cent of the cases showed Grade IV changes. Grade III change was seen in the earlier age groups also, 27 per cent of cases in age group forty to forty-nine years and 12 per cent of cases between 
twenty and thirty-nine years of age revealing it. The proportion of cases showing involvement with Grade III change gradually increased to 42 per cent at age seventy to seventy-nine years (Fig. 6).

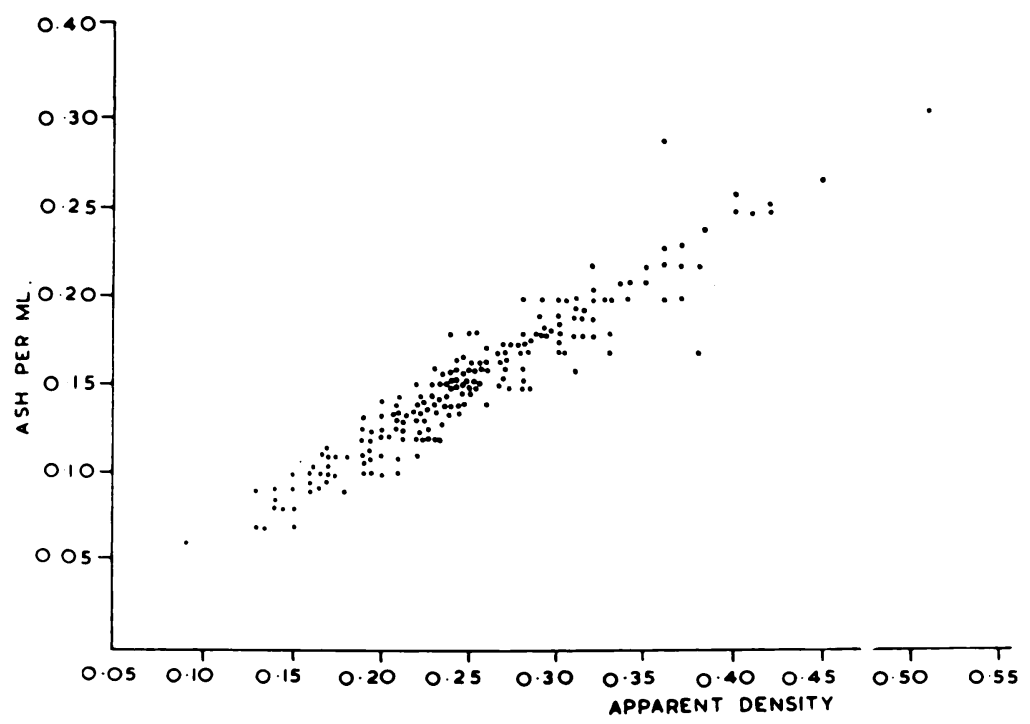

FIG. 5

Scattergraph showing the correlation between apparent density and ash content per millilitre of vertebral medullary tissue in individual cases.

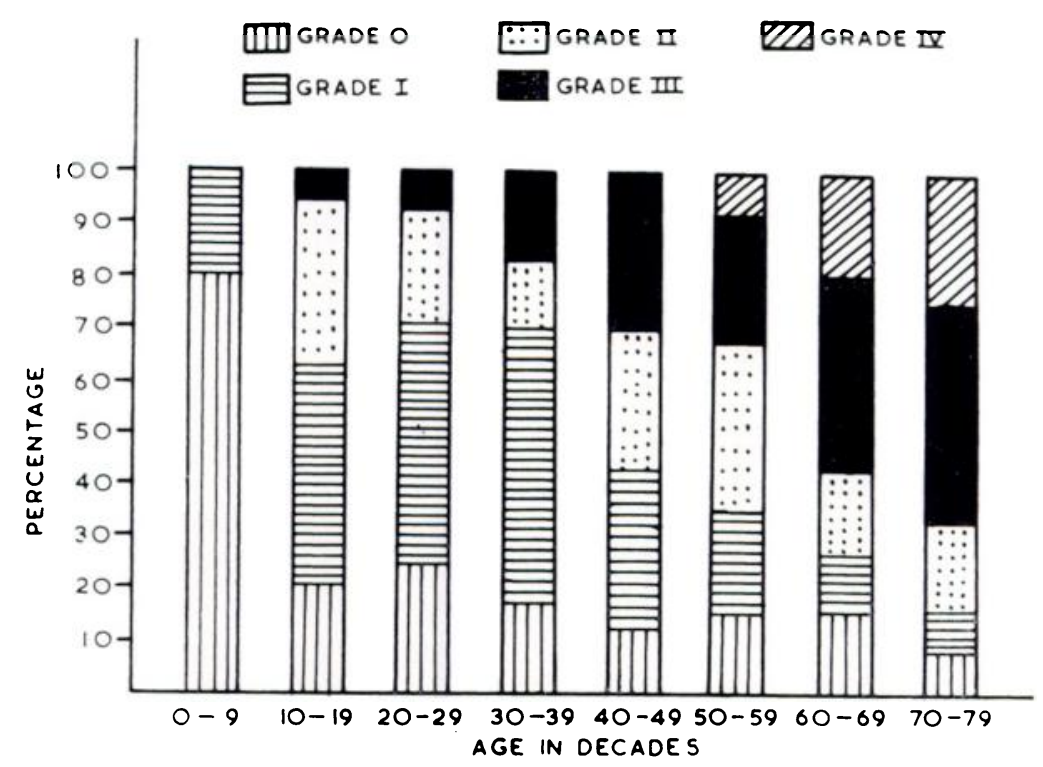

FIG. 6

Histogram showing the distribution of the visual grades of porosity with respect to age in decades.

Relationship between visual porosity, apparent density and ash per millilitre of vertebraTable VI shows the mean apparent density and ash per millilitre of vertebral medullary tissue in relation to the various grades of porosity. It will be seen that the density and ash per 
millilitre are greatest for cases showing Grade 0 porosity and decrease with each subsequent grade. The mean apparent density and ash per millilitre values in Grades III and IV are significantly lower than the corresponding values in Grade $0(\mathrm{P}<\cdot 001)$.

TABLE VI

Mean Apparent Density and Mean Ash/Millilitre of Vertebral Medullary Tissue With Respect to Grades of Visual Porosity

(200 cases)

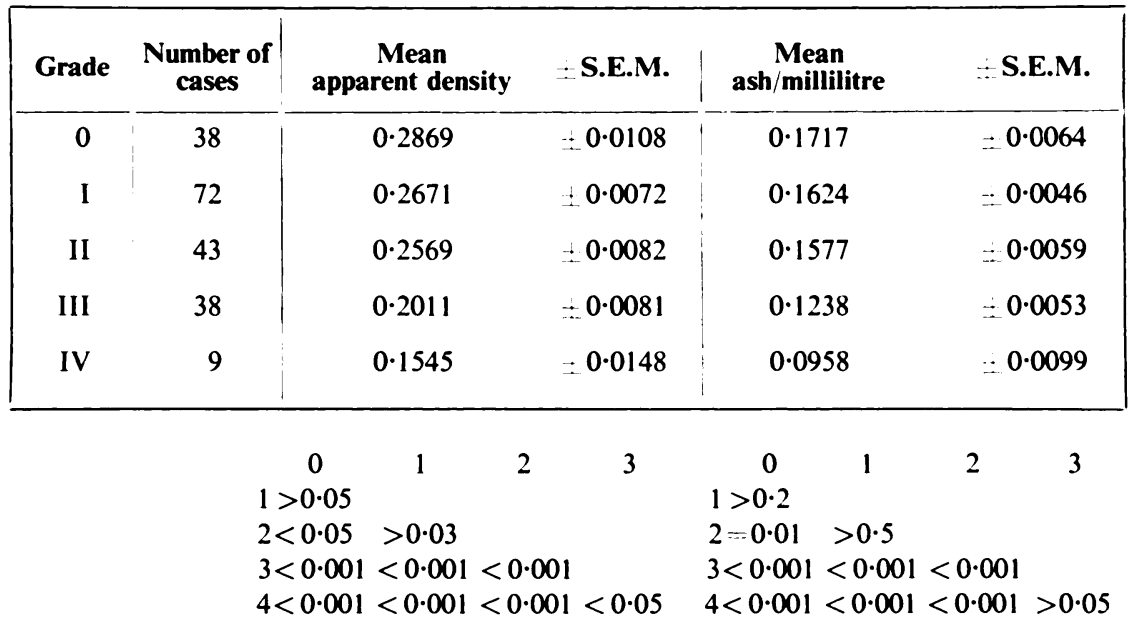

TABLE VII

Mean Apparent Density of Iliac Crest with Respect to Age and Sex (140 cases)

\begin{tabular}{|c|c|c|c|c|c|c|c|c|c|}
\hline \multirow{2}{*}{$\begin{array}{c}\text { Age } \\
\text { (years) }\end{array}$} & \multicolumn{3}{|c|}{ Male } & \multicolumn{3}{|c|}{ Female } & \multicolumn{3}{|c|}{ Combined (males and females) } \\
\hline & $\begin{array}{c}\text { Number of } \\
\text { cases }\end{array}$ & Mean & S.D. & $\begin{array}{l}\text { Number of } \\
\text { cases }\end{array}$ & Mean & S.D. & $\begin{array}{l}\text { Number of } \\
\text { cases }\end{array}$ & Mean & S.D. \\
\hline $10-19$ & 8 & $0 \cdot 5469$ & $=0.1149$ & 6 & 0.6378 & $\therefore 0 \cdot 1600$ & 14 & 0.5850 & $\therefore 0 \cdot 1356$ \\
\hline $20-29$ & 26 & $0 \cdot 6280$ & $\pm 0 \cdot 1563$ & 13 & 0.6295 & $0 \cdot 1321$ & 39 & $0 \cdot 6285$ & $0 \cdot 1483$ \\
\hline $30-39$ & 16 & $0 \cdot 6205$ & \pm 0.1196 & 7 & $0 \cdot 5968$ & $0 \cdot 1070$ & 23 & 0.6140 & $0 \cdot 1162$ \\
\hline $40-49$ & 19 & 0.5110 & $=0.1168$ & 3 & 0.5450 & $0 \cdot 1350$ & 22 & 0.5151 & $0 \cdot 1187$ \\
\hline $50-59$ & 20 & $0 \cdot 5101$ & \pm 0.0725 & 5 & 0.5502 & 0.1185 & 25 & $0 \cdot 5181$ & $\therefore 0.0825$ \\
\hline $60-69$ & 6 & 0.4744 & $\pm 0 \cdot 1076$ & 3 & $0 \cdot 3953$ & $\approx 0.1449$ & 9 & $0 \cdot 4485$ & $\therefore 0 \cdot 1196$ \\
\hline $70-79$ & 7 & 0.4775 & $\pm 0 \cdot 1049$ & 1 & 0.3550 & & 8 & 0.4662 & $0 \cdot 1049$ \\
\hline
\end{tabular}

Microscopic features-In microscopic study a marked reduction in the size and number of bony trabeculae was observed in cases showing Grades III and IV porosity. No attempt was made to grade the severity of histological change. The sections were examined mainly to exclude the presence of any pathological lesion.

\section{ILIAC CREST}

The mean apparent density for males and females according to each decade is shown in Table VII. There is a decline in mean values from the third decade onwards and the mean VOL. 51 B, NO. 4, NOVEMBER 1969 
values in females are comparatively lower. Regression (linear) analysis was done separately for each sex for age groups twenty years and above. The slopes of the regression lines are highly significant for both males and females $(\mathrm{P}<\cdot 001)$. Although in females the decline seems to be more marked, the difference between these lines was not significant $(P>0 \cdot 5)$. Therefore a common regression line for males and females together was constructed (Fig. 7). The slope shows an average decline of 0.0396 per decade in apparent density - that is, a decrease of 6.28 per cent of the expected apparent density in the third decade.

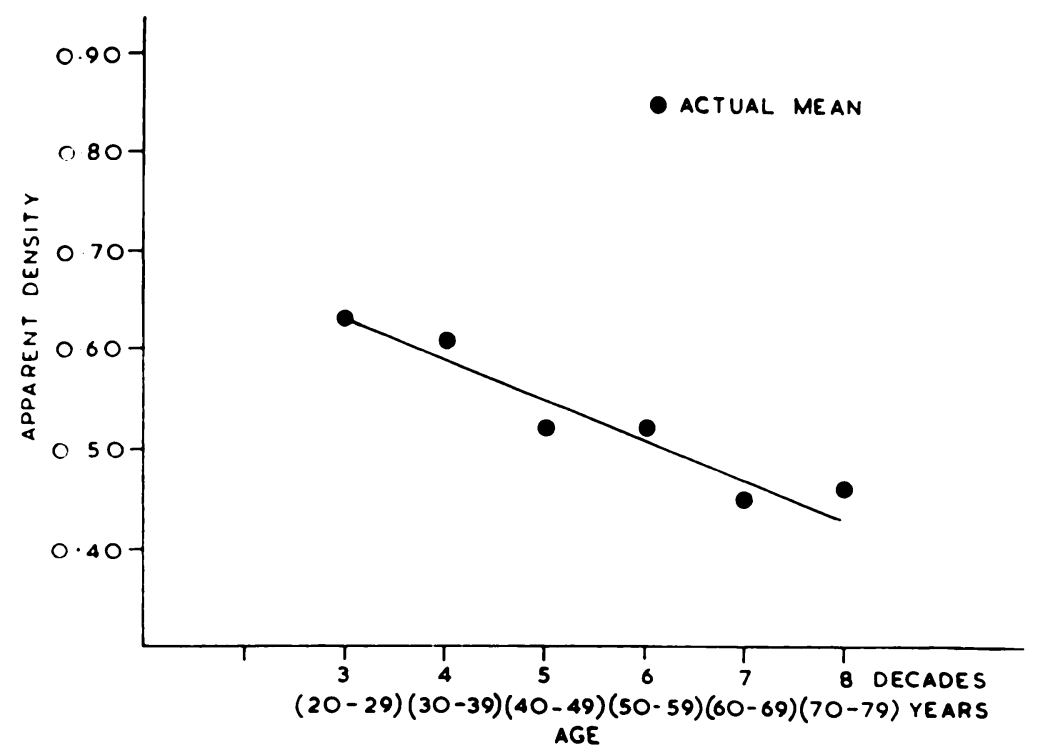

Fig. 7

Regression line of apparent density of iliac crest on age in decades (males and females combined).

RIB

Table VIII shows the mean apparent density of rib in males and females for various decades. The mean values in females are lower than in males. Again a decline in mean values from the third decade onwards is evident. Regression analysis reveals highly significant decline of apparent density with age after the third decade $(\mathrm{P}<\cdot 001)$ (Fig. 8). The regression lines for males and females show a significant difference $(\mathrm{P}<\cdot 001)$. The average decline of apparent density in males is 0.0551 per decade-that is a decrease of 8.42 per cent of the expected value at the third decade. In females the average decline is 0.0455 per decade-a decrease of 8.37 per cent. The difference in slope with respect to sex was not statistically significant $(\mathrm{P}>\cdot 05)$.

FEMUR

The mean apparent density and "femur score" for males and females in various decades is shown in Table IX. No definite trend of decline of apparent density with age is noted. The females seem to have lower mean apparent density in most decades than males. The average density \pm S.E. for all age groups combined is $1.5090 \pm 0.026$ for males and $1.4226 \pm$ 0.044 for females. The difference between these is not significant $(P>05)$. The mean density of femur for males and females combined is 1.4870 . The mean femur score \pm S.E. for males was $51 \cdot 49 \pm 1.54$ and for females $51 \cdot 43 \pm 2 \cdot 86$. It did not differ significantly between the two sexes nor did it show any clear-cut trend with age. Although in females in the eighth decade the value is quite low, much significance cannot be placed on it because this was a single observation. 
Table $X$ shows the correlation between the various bones studied with regard to apparent density. The apparent density of iliac crest and rib shows a significant positive correlation with that of the vertebra $(\mathrm{P}<\cdot 001)$, while the femur does not reveal any correlation with any of the other bones.

TABLE VIII

Mean Apparent Density of Rib with Respect to Age and Sex (140 cases)

\begin{tabular}{|c|c|cc|ccc|}
\hline \multirow{2}{*}{$\begin{array}{c}\text { Age } \\
\text { years })\end{array}$} & \multicolumn{4}{|c}{ Male } & \multicolumn{4}{c|}{ Female } \\
\cline { 2 - 7 } & $\begin{array}{c}\text { Number of } \\
\text { cases }\end{array}$ & Mean & \pm S.D. & $\begin{array}{c}\text { Number of } \\
\text { cases }\end{array}$ & Mean & \pm S.D. \\
\cline { 1 - 7 } $10-19$ & 8 & 0.5325 & \pm 0.1204 & 6 & 0.5661 & \pm 0.1344 \\
$20-29$ & 26 & 0.6841 & \pm 0.1856 & 13 & 0.5366 & \pm 0.1597 \\
$30-39$ & 16 & 0.5592 & \pm 0.1668 & 7 & 0.5107 & \pm 0.0724 \\
$40-49$ & 19 & 0.5167 & \pm 0.1121 & 3 & 0.4593 & \pm 0.1634 \\
$50-59$ & 20 & 0.4973 & \pm 0.1302 & 5 & 0.4637 & \pm 0.1127 \\
$60-69$ & 6 & 0.4485 & \pm 0.1383 & 3 & 0.3263 & \pm 0.0002 \\
$70-79$ & 7 & 0.4054 & \pm 0.0922 & 1 & 0.2220 & \\
\hline
\end{tabular}

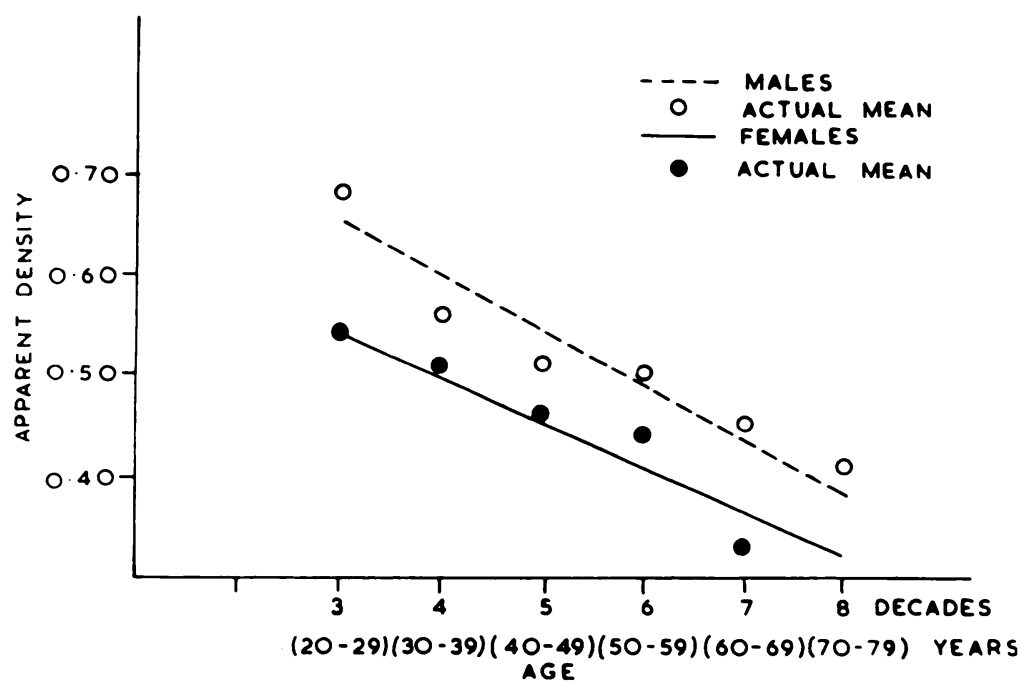

FIG. 8

Regression line of apparent density of rib on age in decades (males and females separately).

DISCUSSION

Several studies from western countries have shown that after an initial increase from infancy to adulthood the bone mass shows a gradual and steady decline throughout adult life and that women lose far more bone than men (Trotter et al. 1960; Garn, Rohmann and Wagner 1967; Newton-John and Morgan 1968). The present study reveals a similar trend in the Indian population; the bone mass begins to diminish after the third decade and this decline continues throughout life. The magnitude of bone loss per decade, after the third decade, was approximately 6 per cent of the value in the third decade. Women seem to lose more bone than men after the fifth decade but this difference is not statistically significant. 
The rate of bone loss is similar to that reported for the Caucasian groups from the West (Newton-John and Morgan 1968). Garn et al. (1967), on the basis of close agreement of figures collected by them from the United States and various Central and South American countries with those collected by Nordin in a World Health Organisation survey (1964), concluded that bone loss with age was a universal phenomenon. They also regard the magnitude

TABLE IX

Mean Apparent Density and "Score" of Femur with Respect to Age and Sex (122 cases)

\begin{tabular}{|c|c|c|c|c|c|c|c|c|}
\hline \multirow{3}{*}{$\begin{array}{c}\text { Age } \\
\text { (years) }\end{array}$} & \multicolumn{4}{|c|}{ Apparent density } & \multicolumn{4}{|c|}{ Femur "score" } \\
\hline & \multirow[b]{2}{*}{$\begin{array}{l}\text { Number } \\
\text { of cases }\end{array}$} & Male & \multicolumn{2}{|r|}{ Female } & \multicolumn{2}{|r|}{ Male } & \multicolumn{2}{|r|}{ Female } \\
\hline & & Mean S.D. & $\begin{array}{l}\text { Number } \\
\text { of cases }\end{array}$ & Mean S.D. & $\begin{array}{l}\text { Number } \\
\text { of cases }\end{array}$ & Mean \pm S.D. & $\begin{array}{l}\text { Number } \\
\text { of cases }\end{array}$ & $\mathbf{s}$ sean $=$ S.D. \\
\hline $10-19$ & 8 & $1.4008=0.3115$ & 3 & $1 \cdot 5280=0 \cdot 2721$ & 9 & $50 \cdot 60=8 \cdot 57$ & 3 & $53 \cdot 03=2.74$ \\
\hline $20-29$ & 23 & $1 \cdot 5199=0 \cdot 1822$ & 12 & $1.4032 \pm 0.2341$ & 23 & $48.94=16.52$ & 10 & $51 \cdot 66=20 \cdot 18$ \\
\hline $30-39$ & 13 & $1 \cdot 5781=0.2796$ & 5 & $1 \cdot 5256=0 \cdot 2341$ & 13 & $52 \cdot 54=6.54$ & 5 & $52 \cdot 86 \doteq 3.66$ \\
\hline $40-49$ & 18 & $1 \cdot 5140 \pm 0.2011$ & 4 & $1 \cdot 3901 \div 0 \cdot 3503$ & 15 & $53.08=5.45$ & 2 & $55 \cdot 1=7.92$ \\
\hline $50-59$ & 14 & $1 \cdot 5910 \pm 0.2498$ & 4 & $1.4039-0.1831$ & 12 & $54.93 \pm 7.6$ & 4 & $50.5=9.04$ \\
\hline $60-69$ & 7 & $1 \cdot 3702=0.2318$ & 2 & $1 \cdot 4096 \pm 0 \cdot 1840$ & 7 & $50.43 \pm 5.68$ & 1 & $50 \cdot 0$ \\
\hline $70-79$ & 8 & $1.4392=0.3591$ & 1 & $1 \cdot 0555$ & 7 & $50 \cdot 87=35 \cdot 62$ & 1 & $35 \cdot 0$ \\
\hline $\begin{array}{l}\text { Overall } \\
\text { mean } \\
\pm \text { S.D. }\end{array}$ & 91 & $\begin{array}{l}1.5090 \\
-0.245\end{array}$ & 31 & $\begin{array}{l}1 \cdot 4226 \\
0 \cdot 249\end{array}$ & 86 & $\begin{aligned} & 51 \cdot 49 \\
\pm & 14 \cdot 3\end{aligned}$ & 26 & $\begin{aligned} & 51 \cdot 43 \\
\pm & 14.6\end{aligned}$ \\
\hline $\begin{array}{l}\text { Combinec } \\
\text { mean } \\
\pm \text { S.D. }\end{array}$ & 122 & $\begin{aligned} & 1.4870 \\
+ & 0.247\end{aligned}$ & & & & $\begin{aligned} & 51 \cdot 48 \\
\pm & 14.3\end{aligned}$ & & \\
\hline
\end{tabular}

for males and females

Femur "score" could not be calculated in ten cases because the sample was inadequate.

TABLE $X$

Relationship Between Apparent Density of Samples of Vertebra,

Illac Crest, Rib and FEMUR

\begin{tabular}{|lccc|}
\hline \multicolumn{1}{|c}{ Bones } & Number & $\begin{array}{c}\text { Product moment } \\
\text { correlation } \\
\text { coefficient }\end{array}$ & p \\
\hline Vertebra and crest . & 140 & 0.3764 & $<0.001$ \\
Vertebra and rib. & 140 & 0.4234 & $<0.001$ \\
Crest and rib & 140 & 0.5598 & $<0.001$ \\
Vertebra and femur & 98 & 0.1973 & N.S. \\
\hline
\end{tabular}

of sexual dimorphism in bone loss to be reasonably well established. Nordin (1966) reported that although the reduction in spinal density and in metacarpal thickness became apparent in women of all countries in the fifth and sixth decades, this process seemed to start earlier in Japanese and Indian women than in British and American women and that it was rather 
late to start in women from Finland. Negroes are reported to lose much less bone with age than the white people (Trotter et al. 1960, Smith and Rizek 1966).

There is some evidence to suggest that the axial and appendicular skeleton lose mass simultaneously (Urist, Zaccalini, MacDonald and Skoog 1962; Smith and Frame 1965).

TABLE XI

Comparison of the Various Studies on Bone Density* (Dry) Determined as Coefficient of Weight by VOLUME OF THE BONE

\begin{tabular}{|c|c|c|c|c|c|c|}
\hline Author & Country & Apparent density & $\begin{array}{c}\text { Ash/ } \\
\text { millilitre }\end{array}$ & $\frac{\text { Rib }}{\begin{array}{c}\text { Apparent } \\
\text { density }\end{array}}$ & $\begin{array}{c}\text { Iliac crest } \\
\text { Apparent } \\
\text { density }\end{array}$ & $\begin{array}{c}\text { Femur } \\
- \\
\text { Apparent } \\
\text { density }\end{array}$ \\
\hline $\begin{array}{c}\text { Trotter et al. } \\
(1960) \\
(80 \text { cadavers } \\
25-100 \text { years })\end{array}$ & $\begin{array}{l}\text { United } \\
\text { States of } \\
\text { America }\end{array}$ & $\begin{array}{l}\text { White } \\
\text { Male } 0.415=0.096 \\
\text { Female } 0.380=0.080 \\
\text { Negro } \\
\text { Male } 0.483 \pm 0.097 \\
\text { Female } 0.453=0.141\end{array}$ & - & $\begin{array}{l}0.612 \div 0.140 \\
0.638 \div 0.133 \\
0.684 \div 0.145 \\
0.675 \div 0.269\end{array}$ & 一 & $\begin{array}{l}0.628 \\
0.598 \\
\\
0.700 \\
0.652\end{array}$ \\
\hline $\begin{array}{c}\text { Atkinson et al. } \\
\text { (1962) } \\
\text { (98 cadavers } \\
20-90 \text { years) }\end{array}$ & $\begin{array}{c}\text { United } \\
\text { Kingdom }\end{array}$ & - & 一 & - & - & range $1 \cdot 5-1 \cdot 0$ \\
\hline $\begin{array}{c}\text { Baker and Angel } \\
\text { (1965) } \\
\text { (48 cadavers } \\
>40 \text { years, } \\
\text { majority } \\
\text { over } 65 \text { years) }\end{array}$ & $\begin{array}{l}\text { United } \\
\text { States of } \\
\text { America }\end{array}$ & $\begin{array}{l}\text { White } \\
\text { Male } 0.280 \pm 0.136 \\
\text { Female } 0.280 \pm 0.070 \\
\text { Negro } \\
\text { Male } 0.410 \pm 0.207 \\
\text { Female } 0.339 \pm 0.057\end{array}$ & $\begin{array}{l}0.165 \pm 0.069 \\
0.135 \pm 0.046 \\
0.251 \pm 0.111 \\
0.158 \pm 0.042\end{array}$ & $\begin{array}{l}0.537=0.134 \\
0.502 \pm 0.125 \\
0.791 \div 0.339 \\
0.558 \pm 0.109\end{array}$ & - & 一 \\
\hline $\begin{array}{l}\text { Arnold (1964) } \\
\text { (78 cadavers } \\
1-85 \text { years) }\end{array}$ & $\begin{array}{l}\text { United } \\
\text { States of } \\
\text { America }\end{array}$ & $0.04-0.18$ & - & - & - & - \\
\hline $\begin{array}{l}\text { Lindahl and } \\
\text { Lindgren (1962) } \\
\text { (60 cadavers } \\
14-91 \text { years) }\end{array}$ & \begin{tabular}{|} 
Scandi- \\
navia
\end{tabular} & $\begin{array}{c}\text { Mean for } 14-29 \text { years } \\
\text { age group } \\
0 \cdot 30\end{array}$ & - & - & - & - \\
\hline $\begin{array}{c}\text { Weaver and } \\
\text { Chalmers (1966) } \\
\text { (137 cadavers } \\
\text { all ages) }\end{array}$ & $\begin{array}{l}\text { United } \\
\text { Kingdom }\end{array}$ & - & $\begin{array}{ll}\text { Male } & 0 \cdot 135 \\
\text { Female } & 0 \cdot 120 \\
\text { Overall } 0.128 \\
50 \text { years } 0 \cdot 116 \\
50 \text { years } 0.153\end{array}$ & - & - & - \\
\hline $\begin{array}{c}\text { Baker and Little } \\
\text { (1965) } \\
\text { (48 cadavers } \\
26-81 \text { years) }\end{array}$ & Peru & $\begin{array}{l}\text { Lima } \\
\text { Male } 0.283 \pm 0.056 \\
\text { High land } \\
\text { Male } 0.225 \pm 0.074 \\
\text { Female } 0.300 \pm 0.083\end{array}$ & $\begin{array}{l}0.180=0.035 \\
0.138 \pm 0.048 \\
0.179 \pm 0.049\end{array}$ & $\begin{array}{l}0.678=0.170 \\
0.576 \pm 0.147 \\
0.882 \pm 0.162\end{array}$ & - & - \\
\hline $\begin{array}{c}\text { Ahuja (1969) } \\
\text { (200 cadavers } \\
9 \text { months to } \\
76 \text { years) }\end{array}$ & India & $\begin{array}{c}\text { Mean for } 20-29 \text { years } \\
\text { age group } \\
\text { Male } 0.289 \pm 0.073 \\
\text { Female } 0.279 \pm 0.055\end{array}$ & $\begin{array}{l}0.171 \pm 0.045 \\
0.171 \pm 0.042\end{array}$ & $\begin{array}{l}0.684 \pm 0.186 \\
0.536 \pm 0.159\end{array}$ & $\begin{array}{l}0.628 \pm 0.156 \\
0.629 \pm 0.132\end{array}$ & $\begin{array}{l}1 \cdot 520 \pm 0.182 \\
1 \cdot 400 \pm 0.234\end{array}$ \\
\hline
\end{tabular}

* The values are indicated as mean \pm S.D. unless specified otherwise.

Nevertheless, the process may not involve all the bones at the same time or at the same rate. Nordin (1964) reported a high degree of correlation between the iliac crest biopsy "score" on histological grading and the vertebral body ash weight per unit volume. In a study of the specific gravity of vertebra, iliac crest and femur, he found a highly significant correlation

VOL. 51 B, NO. 4, NOVEMBER 1969 
between the vertebral body and iliac crest samples, but little correlation between these bones and the femur (Nordin 1963). Arnold, Bartley, Tont and Jenkins (1966), in a study on ash content of vertebral body, rib and cortical thinning of femur, noted that, while in women the cortical thinning of the femur revealed good correlation with diminution of ash content per millilitre of vertebra and rib, in men the femoral cortex failed to show atrophy at comparable rates. In the present study, good correlation was observed in the age-associated bone mass changes in the vertebra, iliac crest and rib. The femur did not reveal comparable changes in apparent density and in cortical thickness. It has to be noted, however, that the number of female femurs in older age groups was rather small, and the possibility of significant atrophy of the femur occurring at later age periods remains speculative. Atkinson, Weatherell and Weidmann (1962) and Atkinson and Weatherell (1967) reported a variation in the density of different segments of femur and showed that the effect of ageing was most marked in the part close to the lower end: at the midshaft neither the density nor the cortical thickness revealed much variation with age.

With regard to the normal bone density in the population under study we have made an attempt to find the mean bone density and ash per millilitre for each decade in males and females separately. Because of differences of technique, a direct comparison of our results with those from other centres is not possible. Nevertheless Table XI summarises reported figures from other post-mortem studies and compares them with the results of the present study. It is evident that the apparent density and ash content per millilitre of the bones of the Indian population studied are generally comparable to those reported for Caucasians in North America and Western Europe but are lower than those reported for the American Negro.

To define osteoporosis is a problem not restricted to the clinician or the radiologist; uncertainty is also felt by the morbid anatomist even if he has access to the entire skeleton. The precise standard or normal for bone density, ash content and the like in relation to age and sex are difficult to define, and separation of normal from "osteoporotic" constitutes a difficult task in many borderline cases. Ideally, the normal should be defined for each decade of age and for the sexes separately if a certain amount of bone loss is considered a normal process of ageing. The bone loss beyond the determined range of normal for that age and sex and for that community would then be considered pathological. However, this is for the future: at the present time the diagnosis of osteoporosis is not based on any of these objective criteria, and valid comparisons of the present figures with those from other areas is not possible.

We are therefore forced to adopt another approach. The nine cases which belong to Grade IV in the visual grading system in the present study show significant osteoporosis. The apparent density in these nine cases varied from 0.0967 to 0.1958 except in one case with apparent density of $0 \cdot 2510$. This case showed compression fractures and marked focal thickening of trabeculae due to reinforcement of the architecture. If this case is excluded, the apparent density was never beyond $0 \cdot 2000$. The ash content per millilitre varied from 0.0628 to 0.1267 except for the case described above. On the basis of these observations, we tentatively suggest that apparent bone density of vertebra below $0 \cdot 20$, and ash per millilitre below $0 \cdot 12$, may be considered indicative of significant osteoporosis.

The apparent density of iliac crest was available in six out of these nine cases in Grade IV and varied from 0.3369 to 0.4679 . Since there was a good correlation between apparent density of iliac crest and vertebra we tentatively suggest that if a piece of iliac crest which includes cortical and trabecular portions shows a density of less than $0 \cdot 46$, it probably indicates Grade IV porosity of the lumbar vertebrae. The apparent density of rib did not show any consistent pattern in this group of nine cases. We cannot offer a ready explanation for this, and we cannot, therefore, suggest a lower limit for this bone below which osteoporosis would be expected to be present.

The incidence of osteoporosis in different communities is not known with certainty. Various surveys in the North American population show that it varies from 15 to 50 per cent of the population over the age of sixty-five years (Lutwak and Whedon 1963). In a post-mortem 
study of ash per millilitre of vertebra, Arnold (1964) reported that 30 per cent of subjects over seventy years revealed significant osteoporosis. In Britain osteoporosis is commonly seen among the elderly: Table XII shows the published figures, compared to the results of the present study. Spinal osteoporosis was found to be common in Japan and in India, whereas it was relatively uncommon in Finland (Nordin 1966). Various clinical and radiological studies indicate that negroes are less subject to osteoporosis than whites (Smith, Eyler and Mellinger 1960; Moldawer, Collins, White and Mayfield 1961). Recent epidemiological studies (Solomon 1968) suggest that although senile osteoporosis does occur in all races in South Africa, it appears at a later age and is much less severe and widespread in Bantus than in white people.

In the present study 14.5 per cent of all persons over fifty years of age showed marked osteoporosis of Grade IV. Twenty cases with mild to moderate osteoporosis of Grade III constituted another 29 per cent of all those fifty years and above; so that the total incidence of osteoporosis in our over-fifty population is about $\mathbf{4 4}$ per cent. It is thus apparent that osteoporosis is quite common in the Indian population. It is also noteworthy that although severe osteoporosis was not seen in any of our subjects below the age of fifty years, mild to moderate osteoporotic change (Grade III) was seen in younger age groups also. Thus 23 per

TABLE XII

Incidence of Osteoporosis in the Present Study as Compared to Published Studies FROM THE UNITED KINGDOM

\begin{tabular}{|c|c|c|c|c|}
\hline Author & Material & Method & $\begin{array}{l}\text { Definition of } \\
\text { osteoporosis }\end{array}$ & $\begin{array}{l}\text { Incidence } \\
\text { ( per cent) }\end{array}$ \\
\hline Collins (1959) & $\begin{array}{c}\text { Vertebrae } \\
\text { (336 necropsies) }\end{array}$ & $\begin{array}{l}\text { Specific gravity of } \\
\text { vertebral samples }\end{array}$ & $\begin{array}{l}<1.05 \text { mild } \\
<1.025 \text { severe }\end{array}$ & $\begin{array}{cc}\text { Male } & \text { Female } \\
7 & 15 \\
1 & 3 \\
\text { (over } & 40 \text { years) }\end{array}$ \\
\hline $\begin{array}{l}\text { Beck and Nordin } \\
(1960)\end{array}$ & $\begin{array}{c}\text { Iliac crest } \\
\text { (275 necropsies) }\end{array}$ & $\begin{array}{l}\text { Histological } \\
\text { grading }\end{array}$ & $\begin{array}{c}<16 \text { per cent bone in } \\
\text { total area }\end{array}$ & $\begin{array}{lc}12 & 23 \\
(20-90 & \text { years })\end{array}$ \\
\hline $\begin{array}{l}\text { Caldwell and } \\
\text { Collins (1961) }\end{array}$ & $\begin{array}{c}\text { Vertebrae } \\
\text { (300 necropsies) }\end{array}$ & $\begin{array}{l}\text { Calcium content } \\
\text { of vertebra } \\
\text { weight/volume }\end{array}$ & $<60 \underset{\text { per milligrams calcium }}{\text { militre }}$ & $\begin{array}{lc}22 \cdot 6 & 23 \cdot 1 \\
\text { (over } 50 \text { years) }\end{array}$ \\
\hline Ahuja (1969) & $\begin{array}{c}\text { Vertebrae } \\
\text { (200 necropsies) }\end{array}$ & $\begin{array}{l}\text { Visual grading } \\
\text { of macerated } \\
\text { vertebral samples }\end{array}$ & $\begin{array}{l}\text { Grade III mild } \\
\text { Grade IV severe }\end{array}$ & $\begin{array}{c}29 \\
14.5 \\
\text { (over } 50 \text { years) }\end{array}$ \\
\hline
\end{tabular}

cent of all subjects between forty and forty-nine years and 12 per cent of all those between twenty and thirty-nine years of age showed osteoporosis of mild to moderate grade. It is true that the body weights of subjects in the present study were generally below "ideal" normal and the possible role of underlying chronic malnutrition might be of importance. However, the precise etiology of such a seemingly high incidence of osteoporosis in the older population and its significant occurrence in young adults remains unknown.

\section{SUMMARY AND CONCLUSIONS}

1. A review of the literature on the normal variations in bone mass in a given population in relation to age, sex, nutritional and genetic background shows several lacunae in our knowledge. Consequently, the separation of milder degrees of osteoporosis is difficult and the definition of osteoporosis itself is uncertain.

2. This paper presents a necropsy study to determine variations in the bone mass that occur with age and sex in a normal Indian population in the Delhi area. Two hundred persons between nine months and seventy-six years of age who died by accident and with no evidence of chronic disease were studied.

VOL. 51 B, NO. 4, NOVEMBER 1969 
3. The parameters of bone mass employed were: apparent bone density, ash per millilitre of bone, cortical thickness and visual grading of porosity of bone in macerated specimens. The first lumbar vertebra, the iliac crest, the fourth rib and the femoral shaft were the bones evaluated.

4. After an initial rise up to the third decade, the apparent bone density and ash per millilitre showed a progressive and significant decline with age in all the three trabecular bones: vertebra, iliac crest and rib. Although these values were in general lower in the females than in males at all ages, and the rate of decrease with age was faster in them than in males, it was only in the rib that a statistically significant difference between the sexes could be established with respect to decrease with age.

5. Decreases in apparent bone density and ash per millilitre of the vertebral bone with age were associated with an increase with age in the porosity as assessed by visual grading.

6. In the case of the femur no significant change was demonstrable with age in any of the parameters used in the present study.

7. From a comparison of the values for apparent density and ash per millilitre with grading of macerates and histological preparations, it is suggested that osteoporosis may be said to be present in this population if the apparent bone density is less than 0.20 and 0.46 in the vertebra and the iliac crest respectively or if the ash per millilitre is less than $0 \cdot 12$ in the vertebra. 8. The study has revealed that $\mathbf{4 4}$ per cent of persons studied in this sample over the age of fifty exhibit significant osteoporosis. It is considered possible that nutritional factors such as protein-calorie malnutrition may be responsible for this relatively high incidence.

This work formed part of a study under the research post-doctoral fellowship programme of the Indian Council of Medical Research. I am grateful: to the Director-General for permission to submit this for publication, to Professor V. Ramalingaswami for his valuable guidance at various stages of this study and for his help in the final preparation of the manuscript, to Dr Walter C. J. Putschar of the United States of America for his many useful suggestions regarding the organisation of this study, to $\mathrm{Mr}$ T. N. Sugathan for statistical analysis, to

Dr S. Bhargava for her help in radiological assessment of bone porosity, and to Dr J. Chandra and Dr S. S. Kaushal for kindly allowing access to the material from medico-legal necropsies.

\section{REFERENCES}

ARnold, J. S. (1964): The Quantitation of Bone Mineralization as an Organ and Tissue in Osteoporosis. In Dynamic Studies of Metabolic Bone Disease, p. 59. Edited by O. H. Pearson and G. F. Joplin. Oxford: Blackwell Scientific Publications.

Arnold, J. S., Bartley, M. H., Tont, S. A., and Jenkins, D. P. (1966): Skeletal Changes in Aging and Disease. Clinical Orthopaedics and Related Research, 49, 17.

Atkinson, P. J., and Weatherell, J. A. (1967): Variation in the Density of the Femoral Diaphysis with Age. Journal of Bone and Joint Surgery, 49-B, 781.

Atkinson, P. J., Weatherell, J. A., and Weidmann, S. M. (1962): Changes in Density of the Human Femoral Cortex with Age. Journal of Bone and Joint Surgery, 44-B, 496.

Baker, P. T., and ANGel, J. L. (1965): Old Age Changes in Bone Density: Sex and Race Factors in the United States. Human Biology, 37, 104.

Baker, P. T., and Little, M. A. (1965): Bone Density Change with Age, Altitude, Sex and Race Factors in Peruvians. Human Biology, 37, 122.

Barnetr, E., and Nordin, B. E. C. (1960): The Radiological Diagnosis of Osteoporosis: A New Approach. Clinical Radiology, 11, 166.

BeCK, J. S., and Nordin, B. E. C. (1960): Histological Assessment of Osteoporosis by Iliac Crest Biopsy. Journal of Pathology and Bacteriology, 80, 391.

Caldwell, R. A., and Collins, D. H. (1961): Assessment of Vertebral Osteoporosis by Radiographic and Chemical Methods Post-mortem. Journal of Bone and Joint Surgery, 43-B, 346.

Collins, D. H. (1959): Degenerative Diseases. In Modern Trends in Diseases of the Vertebral Column, p. 101. Edited by R. Nassim and H. J. Burrows. London: Butterworth \& Co. (Publishers) Ltd.

Garn, S. M., Pao, E. M., and Rihl, M. E. (1964): Compact Bone in Chinese and Japanese. Science, 143, 1439.

Garn, S. M., Rohmann, C. G., and Wagner, B. (1967): Bone Loss as a General Phenomenon in Man. Federation Proceedings, 26, 1729.

Lindahl, O., and Lindgren, A. G. H. (1962): Grading of Osteoporosis in Autopsy Specimens. Acta Orthopaedica Scandinavica, 32, 85. 
Lutwak, L., and Whedon, G. D. (1963): Osteoporosis. Disease-a-month, p. 1, April.

Meema, H. E., and Meema, S. (1963): Measurable Roentgenologic Changes in Some Peripheral Bones in Senile Osteoporosis. Journal of the American Geriatrics Society, 11, 1170.

Moldawer, M., Collins, L. C., White, B. L., and Mayfield, J. D. (1961): Comparison of the Incidence of Osteoporosis in White and Negro Individuals. Clinical Research, 9, 52.

Morgan, D. B., Spiers, F. W., Pulvertaft, C. N., and Fourman, P. (1967): The Amount of Bone in the Metacarpal and the Phalanx According to Age and Sex. Clinical Radiology, 18, 101.

Mueller, K. H., Trias, A., and Ray, R. D. (1966): Bone Density and Composition. Age-Related and Pathological Changes in Water and Mineral Content. Journal of Bone and Joint Surgery, 48-A, 140.

Newton-John, H. F., and Morgan, D. B. (1968): Osteoporosis: Disease or Senescence? Lancet, i, 232.

Nordin, B. E. C. (1963): Osteoporosis. In Bone Metabolism in Relation to Clinical Medicine, p. 113. Edited by H. A. Sissons. London: Pitman Medical Publishing Co. Ltd.

Nordin, B. E. C. (1964): The Relation between Dietary Calcium and Osteoporosis in Different Parts of the World. A Report to the Nutrition Section of the World Health Organisation. Glasgow: privately printed.

Nordin, B. E. C. (1966): International Patterns of Osteoporosis. Clinical Orthopaedics and Related Research. $45,17$.

Robinson, R. A., and ElLiott, S. R. (1957): The Water Content of Bone. Journal of Bone and Joint Surgery, 39-A, 167.

SEAlE, R. U. (1959): The Weight of the Dry Fat-free Skeleton of American Whites and Negroes. American Journal of Physical Anthropology, 17, 37.

Smith, R. W., Eyler, W. R., and Mellinger, R. (1960): On the Incidence of Senile Osteoporosis. Annals of Internal Medicine, 52, 773.

Smith, R. W., and Frame, B. (1965): Concurrent Axial and Appendicular Osteoporosis. New England Journal of Medicine, 273, 73.

Smith, R. W., and Rizek, J. (1966): Epidemiologic Studies of Osteoporosis in Women of Puerto Rico and Southeastern Michigan with Special Reference to Age, Race, National Origin and to Other Related or Associated Findings. Clinical Orthopaedics and Related Research, 45, 31.

Solomon, L. (1968): Osteoporosis and Fracture of the Femoral Neck in the South African Bantu. Journal of Bone and Joint Surgery, 50-B, 2.

Trotter, M., Broman, G. E., and Peterson, R. R. (1960): Densities of Bones of White and Negro Skeletons. Journal of Bone and Joint Surgery, 42-A, 50.

Trotter, M., and Peterson, R. R. (1955): Ash Weight of Human Skeletons in per cent of Dry Fat-Free Weight. Anatomical Record, 123, 341.

Urist, M. R., Zaccalini, P. S., MacDonald, N. S., and Skoog, W. A. (1962): New Approaches to the Problem of Osteoporosis. Journal of Bone and Joint Surgery, 44-B, 464.

Walker, A. R. P., Strydom, E. S. P., Reynolds, P. A., and Grobbelaar, B. G. (1955): The Composition and Density of Thoracic Vertebral Bodies from South African Bantu Adults Habituated to a Very High Iron Intake. South African Journal of Laboratory and Clinical Medicine, 1, 254.

Weaver, J. K., and Chalmers, J. (1966): Cancellous Bone: Its Strength and Changes with Aging and an Evaluation of Some Methods for Measuring its Mineral Content. Journal of Bone and Joint Surgery. 48-A, 289.

Wray, J. B., Sugarman, E. D., and Schneider, A. J. (1963): Bone Composition in Senile Osteoporosis. Journal of the American Medical Association, 183, 118.

Vol. 51 B, No. 4, NOVEMBER 1969 